Check for updates

Cite this: RSC Adv., 2018, 8, 41938

Received 10th November 2018 Accepted 28th November 2018

DOI: $10.1039 / \mathrm{c} 8 \mathrm{ra09291e}$

rsc.li/rsc-advances

\section{Biguanidine functional chitooligosaccharide modified reverse osmosis membrane with improved anti-biofouling property}

\begin{abstract}
Huihui Wang, $\uparrow^{\mathrm{ab}}$ Yixuan Zhou, $\uparrow^{\mathrm{ab}}$ Yao Wang, ${ }^{\text {ab }}$ Zhi Wang (D) *ab and Jixiao Wang (D) ab
In this work, a novel anti-biofouling reverse osmosis (RO) membrane was fabricated by second interfacial polymerization of synthesized cationic biguanidine functional chitooligosaccharide (COSG) with the acyl chloride groups on the nascent RO membrane surface. COSG fully combined the bioactivity of oligosaccharides and guanidine-based polymers. Meanwhile, the chitooligosaccharide (COS)-modified RO membranes were prepared for comparison. Both the COS and COSG modified membrane surface negative charge and roughness were reduced, and the hydrophilicity was significantly improved. The water flux of the COSG-modified membrane increased $16.61 \%$ than that of the virgin membrane, while the salt rejection exhibited slight decrease. Membrane fouling tests of lysozyme and bovine serum albumin illustrated that the COSG-modified membrane exhibited improved anti-fouling property with low flux decline ratios and high flux recovery ratios. Besides, the COSG-modified membranes exhibited excellent anti-bacterial property with mortalities of $99.9 \%$ against both Escherichia coli and Bacillus subtilis. Moreover, the COSG-modified membrane maintained high desalination performance after being immersed in the bacteria suspensions for seven days.
\end{abstract}

\section{Introduction}

As an economical separation technology, reverse osmosis (RO) membrane technology has been used in many fields, and will achieve greater success in ecological restoration and environmental management. ${ }^{1-4}$ However, the membrane fouling has been identified as a challenge which restricts the further development and application of RO membrane technology. ${ }^{5}$ The fouling layer can cause several adverse impacts including higher operating pressure, lower membrane performance, increased energy consumption and shortened membrane life span., ${ }^{6,7}$

Although both the pretreatment of feed solution and membrane cleaning can effectively alleviate membrane fouling, bacteria cannot be fully removed. Once the residual bacteria are adsorbed on the membrane surface, they begin to colonize and produce extracellular polymeric substances (EPSs) in situ and ultimately form a mature biofilm, which makes the biofouling more complex and difficult to control. Many biocides (such as chlorine, ozone) are often applied in the pretreatment process to control biofouling. ${ }^{8}$ However, the active chlorine as an oxidizing

${ }^{a}$ Chemical Engineering Research Center, School of Chemical Engineering and Technology, Tianjin University, Weijin Road 92\#, Nankai District, Tianjin 300072, PR China. E-mail: wangzhi@tju.edu.cn; Tel: +86-22-27404533

${ }^{b}$ Tianjin Key Laboratory of Membrane Science and Desalination Technology, State Key Laboratory of Chemical Engineering, Collaborative Innovation Center of Chemical Science and Engineering (Tianjin), Tianjin University, Tianjin 300072, PR China

$\dagger$ These authors contributed equally to this work. agent has adverse effects on the performance of aromatic polyamide RO membranes. ${ }^{9}$ The dosing of biocides in RO processes maybe also toxic to human, and couldn't be used for potable water production. ${ }^{\mathbf{1 0}}$ Thus, it is urgently needed to develop antibiofouling RO membranes in practical applications.

Currently, many anti-biofouling membranes have been prepared via surface modification. ${ }^{\text {,11-16 }}$ The methods of surface modification include physical coating or deposition, layer by layer self-assembly, free radical initiated polymerization and so on. Among those methods, the second interfacial polymerization (SIP) which utilizes the unreacted active groups on the membrane surface is not only more stable than physical methods but also easier and more effective than most of chemical binding methods. ${ }^{7,14,15,17}$ The anti-biofouling strategies usually focus on improving the anti-adhesive and/or antimicrobial properties of membranes. The surface properties (such as hydrophilicity, roughness, charge) are supposed as essential factors to control membrane biofouling., ${ }^{5,7,18-20}$ Accordingly, many hydrophilic materials (such as poly(ethylene glycol), polyvinyl alcohol, zwitterionic polymers) have been immobilized on the membrane to mitigate biofouling by reducing the interaction between biofoulants and the membrane surface, and suppressing the initial microbial adhesion. ${ }^{15,16,21-23}$ However, they are ineffective to restrain microbial colonization once a small amount of bacteria attached onto the membrane surface. Many biocides which involve metallic nanoparticles (such as $\mathrm{Ag}, \mathrm{Cu}, \mathrm{ZnO} \mathrm{NPs}$ ), antibiotics, quaternary ammonium salts, carbon-based materials (carbon nanotubes, graphene oxide) and $N$-halamines have also 
been incorporated onto the membrane surface to kill the bacteria effectively and reduce the rate of biofilm formation. .2,14,24-27 $^{\text {1. }}$ Nevertheless, the bactericidal surface may make microorganisms attach and colonize on the membrane surface more easily due to the rapid accumulation of dead microbial cells. ${ }^{28}$ Hence, it is more efficient to fabricate anti-biofouling membranes with both anti-adhesive and anti-microbial features..$^{13,29,30}$

As a kind of cationic anti-bacterial agents, biguanides have the broad-spectrum antibacterial property with low mammalian toxicity and have long been applied as medical and food protection agents, antiseptics for industry products and other commodities. ${ }^{31-36}$ The positive charged biguanide groups of biguanides have strong electrostatic interaction with the negative charges of bacterial surface, causing the bacterial cell membrane dissolution and finally the cell death. ${ }^{37}$ Recently, polymeric biguanides have been used to prepare anti-bacterial membranes..$^{38-41}$ However, the desalination performance of the modified membrane was greatly impaired and the modification process was complex and time-consuming.

In order to improve membrane anti-bacterial property while maintain high membrane flux, we chose a hydrophilic chitooligosaccharide (COS) to optimize the surface characteristics. COS is a degraded product of chitin or chitosan. It has several advantages for surface modification due to resource-rich, low cost, water solubility, stability, cytocompatibility and various biological activities. $^{42,43}$ Biological activities of COS include anti-bacterial, anti-fungal, anti-viral, anti-tumor, anti-oxidant, immunoregulatory, exert fat and blood pressure control effects. ${ }^{\mathbf{4 4 , 4 5}}$ Meanwhile, according to molecular dynamics results, this hydrophilic modification may increase the free volume of the membrane as it swells when hydrated and vibrates due to molecular collisions, thereby increasing the water flux of the membrane. ${ }^{46-50}$ Moreover, COS is rich in amine groups, which could be easily functionalized and immobilized onto the nascent RO membrane surface. ${ }^{\mathbf{1 4 , 2 9 , 5 1 , 5 2}}$

In this paper, to simultaneously improve the water flux and anti-biofouling performance of RO membrane, we prepared a biguanidine functional chitooligosaccharide (COSG) and grafted the COSG on the nascent RO membrane by second interfacial polymerization. The biguanide groups of COSG could increase the cationic density and improve the anti-bacterial performance of COS significantly. ${ }^{53}$ The prepared membranes were analyzed by X-ray photoelectron spectroscopy (XPS), scanning electron microscopy (SEM), atomic force microscopy
(AFM), contact angle goniometer and electrokinetic analyzer. Membrane desalination performance was experimentally evaluated. Bovine serum albumin (BSA) and lysozyme were chosen to evaluate the anti-fouling properties of membranes. Escherichia coli (E. coli) and Bacillus subtilis (B. subtilis) were chosen as typical stains to investigate the anti-bacterial and antibiofouling properties of membranes.

\section{Experimental}

\subsection{Materials}

The polysulfone (PSf) ultrafiltration membrane with molecular weight cut off (MWCO) of 30000 dalton was used as supports and purchased from Pureach Corporation (China). (+)-10-camphorsulfonic acid (CSA), triethylamine (TEA), $m$-phenylenediamine (MPD), sodium dodecyl sulfate (SDS), trimesoyl chloride (TMC) and dicyandiamide were bought from Aladdin Reagent Co. Ltd. (China). $N$-Heptane, $n$-hexane, hydrochloric acid (37\%, wt $\%$ ), sodium hydroxide $(\mathrm{NaOH})$, potassium chloride $(\mathrm{KCl})$ and sodium chloride $(\mathrm{NaCl})$ were purchased from Jiangtian Chemical Technology Co. Ltd. (China). COS, with a weight-average molecular weight of $1.5 \mathrm{kDa}$ and a deacetylation degree (DD) of 0.90 , was purchased from Qingdao Medicine Institute, Shandong, China. BSA (96\%) and lysozyme were purchased from Dingguo Changsheng Biotech Co. Ltd. (China). E. coli and B. subtilis were provided by Transgen Biotech Co. Ltd. (China). Pure water with a conductivity of less than $10 \mu \mathrm{S} \mathrm{cm}^{-1}$ was obtained from a RO system.

\subsection{Synthesis and characterization of COSG}

COSG was synthesized by the guanidination reaction of COS and dicyandiamide, according to the previous study. ${ }^{52}$ The synthetic route of COSG is presented in Fig. 1. Initially, COS $(5 \mathrm{~g})$ was dissolved in $50 \mathrm{~mL}$ of hydrochloric acid $\left(0.2 \mathrm{~mol} \mathrm{~L}^{-1}\right)$ under magnetic stirring to form a homogeneous solution. The desired amount of dicyandiamide (corresponding to a molar ratio of $1: 1$ compared with COS) was dissolved in $50 \mathrm{~mL}$ of pure water at $60{ }^{\circ} \mathrm{C}$. Then, the COS solution and dicyandiamide solution were mixed in a $250 \mathrm{~mL}$ three-necked flask and adjusted the $\mathrm{pH}$ value to 1 by hydrochloride solution $\left(5 \mathrm{~mol} \mathrm{~L}^{-1}\right)$. As shown in Fig. 2, the working power of the microwave was set to $400 \mathrm{~W}$. The flask was put in it and stirred at $50{ }^{\circ} \mathrm{C}$ for $15 \mathrm{~min}$. After the guanidination reaction, the mixture was poured into a dialysis bag with molecular weight cut-off of 500. After it was dialyzed for three

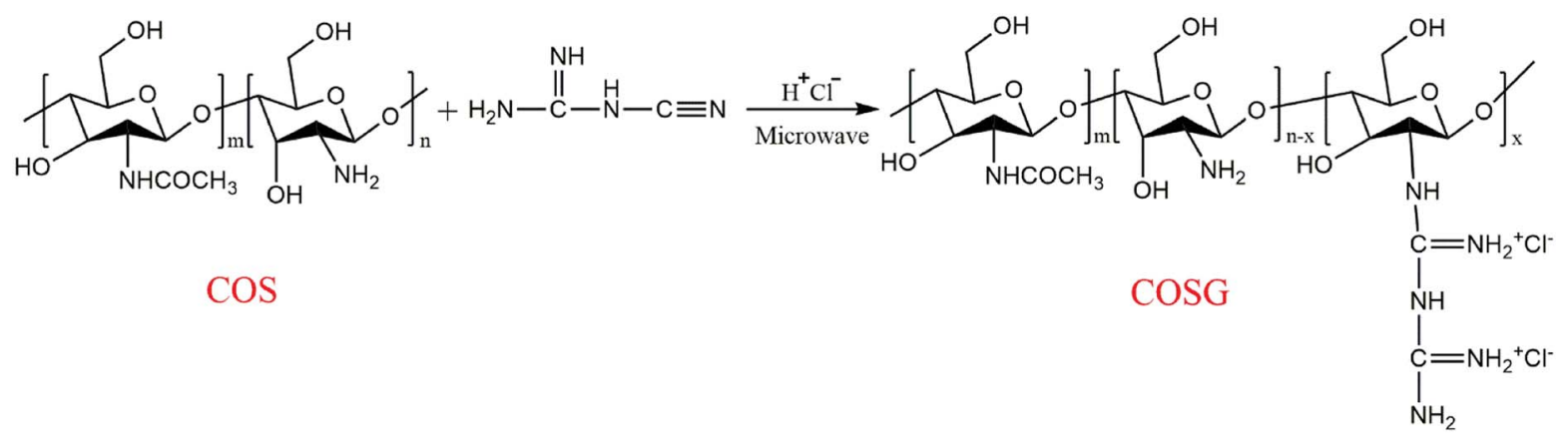

Fig. 1 Synthetic route of COSG. 


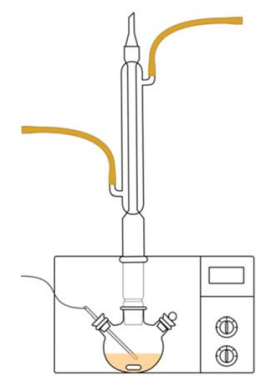

Fig. 2 Schematic diagram of microwave synthesis.

days, the solution was poured into anhydrous ethanol to precipitate. The white precipitates were filtered and washed several times and dried to constant weight at $60{ }^{\circ} \mathrm{C}$. Finally, the dried product named as COSG was obtained.

The chemical structures of COS and COSG were measured by Fourier transform infrared (FTIR) spectroscopy (FTS-6000, Bio-Rad Inc., America). The ${ }^{13} \mathrm{C}-\mathrm{NMR}$ spectra of COS and COSG were measured by a NMR spectrometer (Varian Unity Inova-500 MHz, Varian Associates). Carbon and nitrogen contents of the synthesized COSG were determined by a Vario EL elemental analyzer (Germany).

\subsection{Membrane preparation}

The virgin membrane was prepared through the typical interfacial polymerization (IP) process which was the same as our previous works. ${ }^{54,55}$ Except that, the modification process was convenient and fast. Firstly, two different concentrations of the grafting solutions $\left(0.1 \mathrm{~mol} \mathrm{~L}^{-1} \mathrm{COS}, 0.5 \mathrm{~mol} \mathrm{~L}^{-1} \mathrm{COS}, 0.1 \mathrm{~mol} \mathrm{~L}^{-1}\right.$
COSG, $0.5 \mathrm{~mol} \mathrm{~L}^{-1}$ COSG) were prepared. As shown in Fig. 3, after the first IP reaction, $50 \mathrm{~mL}$ grafting solution was poured on the nascent membrane. It was allowed to the second interfacial polymerization for approximately 1 minute. Then the grafting solution was decanted and the membrane was annealed in the oven at $80^{\circ} \mathrm{C}$ for $6 \mathrm{~min}$. The resulting membranes modified with COS and COSG were named COS-modified membrane and COSG-modified membrane, respectively. Finally, the prepared membranes were rinsed with pure water at room temperature and stored in pure water at $4{ }^{\circ} \mathrm{C}$ before use.

\subsection{Surface properties characterization}

The prepared membranes were dried overnight under vacuum at $40{ }^{\circ} \mathrm{C}$ before test.

The elemental contents of the membrane surface were obtained by XPS (PHI5000VersaProbe, Japan). The morphology of the membrane surface was investigated by SEM (Nova NanoSEM430, USA) and AFM (Bruker Dimension Icon, Germany). The wettabilities of the membranes were evaluated by a contact angle analyser (Data Physics Instruments $\mathrm{GmbH}$, Germany). The zeta potentials of the membranes were evaluated by an electrokinetic analyser (Anton Paar GmbH, Austria). ${ }^{56,57}$

\subsection{Desalination performance evaluation}

The desalination performances of the membranes were tested in a self-made RO test apparatus. ${ }^{54,55}$ The effective area of the membrane cell is $28.26 \mathrm{~cm}^{2}$. The filtration experiment was tested with $2000 \mathrm{mg} \mathrm{L}^{-1} \mathrm{NaCl}$ aqueous solution and under the
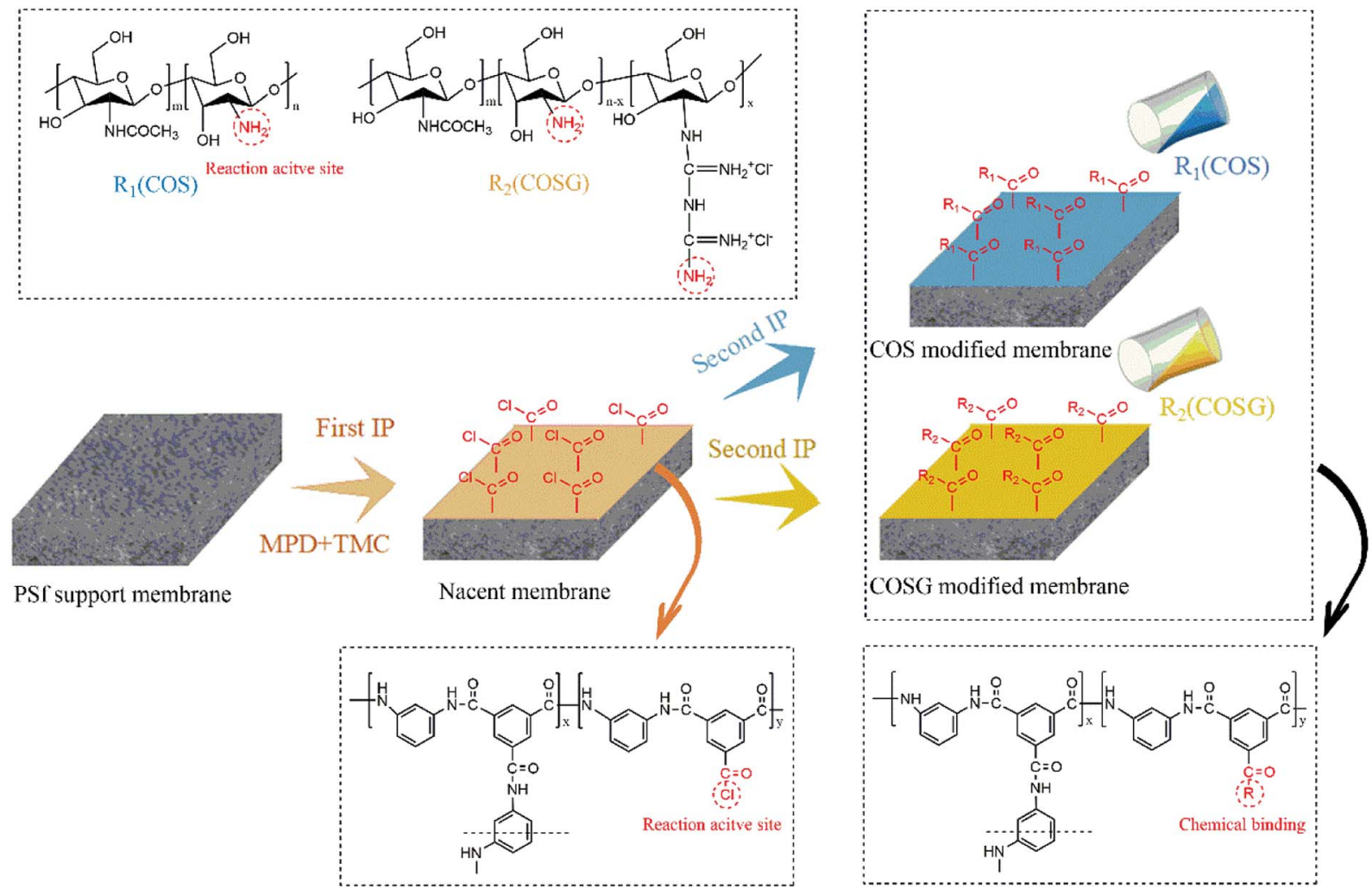

Fig. 3 Schematic diagram of the COS-modified and COSG-modified membrane fabrication process. 
condition of $25.0 \pm 0.1{ }^{\circ} \mathrm{C}, 1.55 \mathrm{MPa}$ trans-membrane pressure (TMP), $1.5 \mathrm{~L} \mathrm{~min}^{-1}$ cross-flow velocity. The water flux $\left(J_{\mathrm{w}}\right)$ was obtained by directly weighing the permeate water. The salt rejection $(R)$ were obtained according to the eqn (1):

$$
R=\left(1-\frac{C_{\mathrm{p}}}{C_{\mathrm{f}}}\right) \times 100 \%
$$

where $C_{\mathrm{p}}$ and $C_{\mathrm{f}}$ represent the salt concentrations of the permeate and feed solution, respectively.

\subsection{Anti-fouling property evaluation}

Lysozyme and BSA were chosen as the model foulants, and the experiment was tested at the same TMP (1.55 MPa). Firstly, a $2000 \mathrm{mg} \mathrm{L}^{-1} \mathrm{NaCl}$ aqueous solution was run for 40 minutes, and the water flux was measured. Then, the foulant with a concentration of $500 \mathrm{mg} \mathrm{L}^{-1}$ was added to the feed solution. The water flux of the membrane was recorded every one minute. After $6 \mathrm{~h}$ test, the feed solution was fully replaced by a $2000 \mathrm{mg} \mathrm{L}^{-1} \mathrm{NaCl}$ solution, and the fouled membrane was rinsed under the condition of $0.62 \mathrm{MPa} 4.0 \mathrm{~L} \mathrm{~min}^{-1}$ for 30 minutes to remove the foulants that loosely deposited on the membrane surface. Finally, the water flux was tested again. After the above test, the membranes were dried overnight under vacuum at $40^{\circ} \mathrm{C}$, and the surface morphology was observed by SEM. The flux decline (FD) and flux recovery (FR) were obtained according to the eqn (2) and (3), respectively:

$$
\begin{gathered}
\mathrm{FD}=\left(1-\frac{J_{1}}{J_{0}}\right) \times 100 \% \\
\mathrm{FR}=\frac{J_{2}}{J_{0}} \times 100 \%
\end{gathered}
$$

where $J_{0}, J_{1}$ and $J_{2}$ represent the initial water flux after precompression for 40 minutes, water flux after fouling for $6 \mathrm{~h}$ and rinsing for 30 minutes, respectively.

\subsection{Anti-bacterial property evaluation}

The E. coli and B. subtilis were chosen to test the anti-bacterial property of the RO membranes by measuring the mortality rate. ${ }^{58}$ The $E$. coli and $B$. subtilis suspension were poured in the nutrient broth and incubated by shaking in a oscillator at $37{ }^{\circ} \mathrm{C}$ for $12 \mathrm{~h}$. The prepared membrane samples were contacted with the bacterial suspensions (cell concentration: $(1.0-1.5) \times 10^{6}$ CFU $\mathrm{mL}^{-1}$, inoculation quantity: $\left.(5.3-8.0) \times 10^{7} \mathrm{CFU} \mathrm{\textrm {m } ^ { - 2 }}\right)$, respectively. The mortality rate at the certain contact time was obtained according to the eqn (4):

$$
M=\frac{B-A}{B} \times 100 \%
$$

where $M, A$ and $B$ represent the mortality rate, the number of viable bacteria after $2 \mathrm{~h}$ of contact and the number of viable bacteria without contact (blank control).

\subsection{Anti-biofouling property evaluation}

The desalination performance and surface morphology of the membranes after biofouling were tested to determine the antibiofouling property. The bacteria suspension (volume: 100 $\mathrm{mL}$; cell concentration: $\left.(1.0-1.5) \times 10^{6} \mathrm{CFU} \mathrm{mL}^{-1}\right)$ was poured on the membrane and incubated at $37{ }^{\circ} \mathrm{C}$ for 7 days, and the fresh nutrient broth was added every $12 \mathrm{~h}$ to remain bacteria active. Finally, the membranes were rinsed with pure water before the anti-biofouling property evaluation.

\section{Results and discussion}

\subsection{COSG characterization}

The FTIR spectra of the COS and COSG in the range of 500$3750 \mathrm{~cm}^{-1}$ are shown in Fig. 4. The band around $3373 \mathrm{~cm}^{-1}$ represents the stretching vibrations of $\mathrm{O}-\mathrm{H}$ and $\mathrm{N}-\mathrm{H}$ groups in the polymer chains, the band around $2890 \mathrm{~cm}^{-1}$ corresponds to the $\mathrm{C}-\mathrm{H}$ stretching vibration, while the band at $1076 \mathrm{~cm}^{-1}$ in the spectrum of COS corresponds to the $\mathrm{N}-\mathrm{H}$ bending vibration of secondary amines in the $-\mathrm{NH}-\mathrm{CO}-\mathrm{CH}_{3}$ group owing to the incomplete deacetylation of COS. Except that, the bands at $1527 \mathrm{~cm}^{-1}$ and $1378 \mathrm{~cm}^{-1}$ correspond to the $\mathrm{N}-\mathrm{H}$ distortion vibration and $\mathrm{C}-\mathrm{N}$ stretching vibration of the guanidine group, respectively. Moreover, the band at $1637 \mathrm{~cm}^{-1}$ corresponds to $\mathrm{C}=\mathrm{N}$ stretching vibration. The three stronger bands at $1637 \mathrm{~cm}^{-1}, 1527 \mathrm{~cm}^{-1}, 1378 \mathrm{~cm}^{-1}$ indicated that the guanidination occurred on COS (as shown in Fig. 1). All these results confirmed that COSG was synthesized successfully. ${ }^{52,53,59}$

The ${ }^{13} \mathrm{C}-\mathrm{NMR}$ spectra of the COS and COSG are shown in Fig. 5. The new chemical peaks of C7 (165.27 ppm) and C8 (155.30 ppm) which were corresponding to the carbons of biguanidine groups demonstrated the successful guanination of COS. ${ }^{52}$

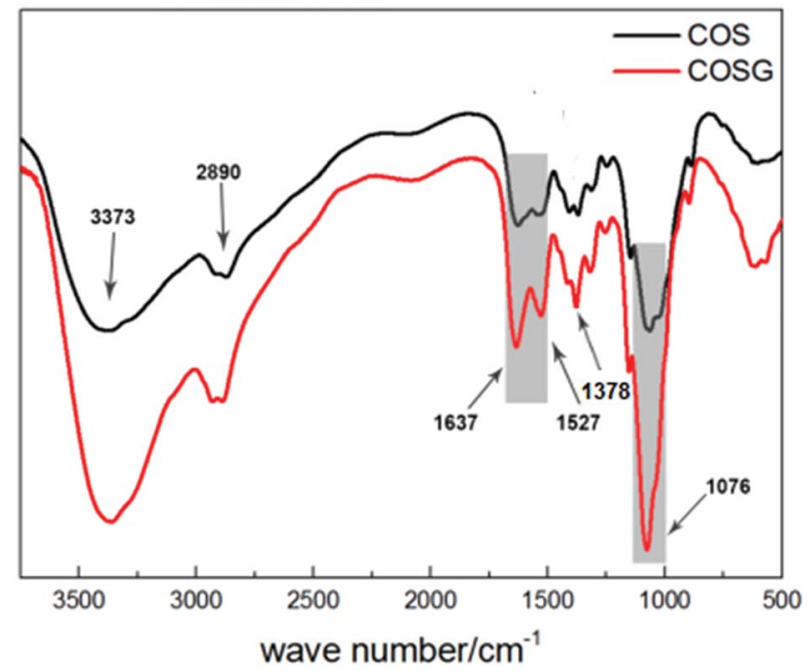

Fig. 4 FTIR spectra of COS and COSG.

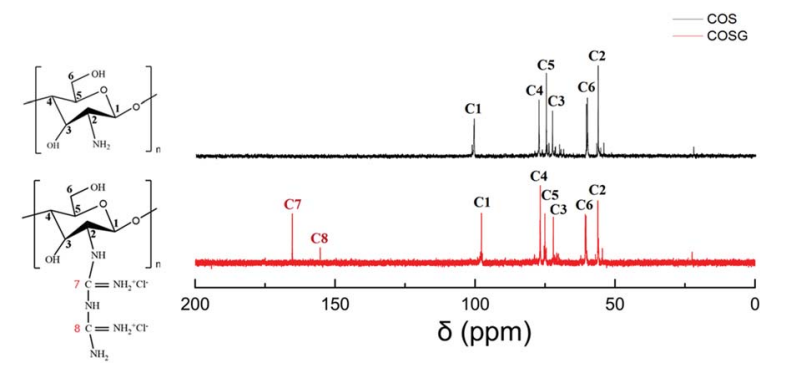

Fig. $5{ }^{13}$ C-NMR spectra of COS and COSG. 
COS are generated by depolymerization of chitin or chitosan, hence the molecular formula of COS can be expressed as $\left(\mathrm{C}_{6} \mathrm{H}_{11} \mathrm{NO}_{4}\right)_{\mathrm{DD}} \cdot\left(\mathrm{C}_{8} \mathrm{H}_{13} \mathrm{NO}_{5}\right)_{1-\mathrm{DD}}{ }^{{ }^{44}}$ Assuming that substitution degree of guanidine is DS, the molecular formula of COSG can be expressed as $\left(\mathrm{C}_{6} \mathrm{H}_{11} \mathrm{NO}_{4}\right)_{\text {DD-DS }} \cdot\left(\mathrm{C}_{8} \mathrm{H}_{13} \mathrm{NO}_{5}\right)_{1}$ ${ }_{D D} \cdot\left(\mathrm{C}_{8} \mathrm{H}_{17} \mathrm{~N}_{5} \mathrm{O}_{4}\right)_{\text {DS }}^{2+} \cdot \mathrm{Cl}_{2 \mathrm{DS}}^{-}$. Thus, the substitution degree of guanidine can be calculated by the eqn (5):

$$
\frac{(\mathrm{C} \%)_{\mathrm{CosG}}}{(\mathrm{N} \%)_{\mathrm{CosG}}}=\frac{12[6(\mathrm{DD}-\mathrm{DS})+8(1-\mathrm{DD})+8 \mathrm{DS}]}{14[(\mathrm{DD}-\mathrm{DS})+(1-\mathrm{DD})+5 \mathrm{DS}]}
$$

The elemental contents ( $\mathrm{C}$ and $\mathrm{N}$ ) of the synthesized COSG were determined by elemental analyzer Vario EL (Germany). As a result, the contents of carbon and nitrogen were $30.12 \%$ and $9.29 \%$, respectively. Based on the eqn (5), the substitution degree of guanidine was $18.45 \%$. Thus, the molecular formula of the synthesized COSG $\left(\mathrm{C}_{6} \mathrm{H}_{11} \mathrm{NO}_{4}\right)_{0.7155} \cdot\left(\mathrm{C}_{8} \mathrm{H}_{13} \mathrm{NO}_{5}\right)_{0.1} \cdot\left(\mathrm{C}_{8} \mathrm{H}_{17} \mathrm{~N}_{5} \mathrm{O}_{4}\right)_{0.1845}^{2+} \cdot \mathrm{Cl}_{0.369}{ }^{-}$.

\subsection{Surface properties characterization}

3.2.1. XPS analysis. The elemental compositions of membranes were characterized by XPS. As Table 1, the COS-

Table 1 The elemental contents and surface zeta potential of the virgin, COS-modified and COSG-modified membranes

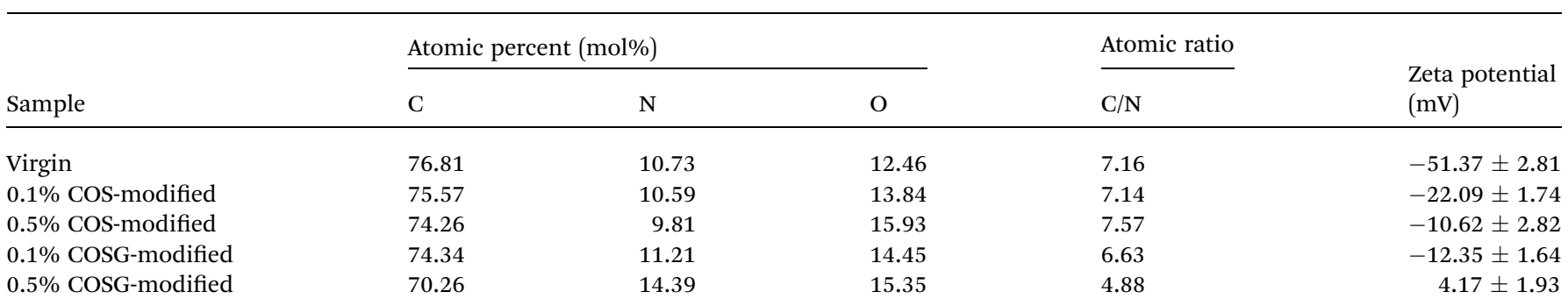
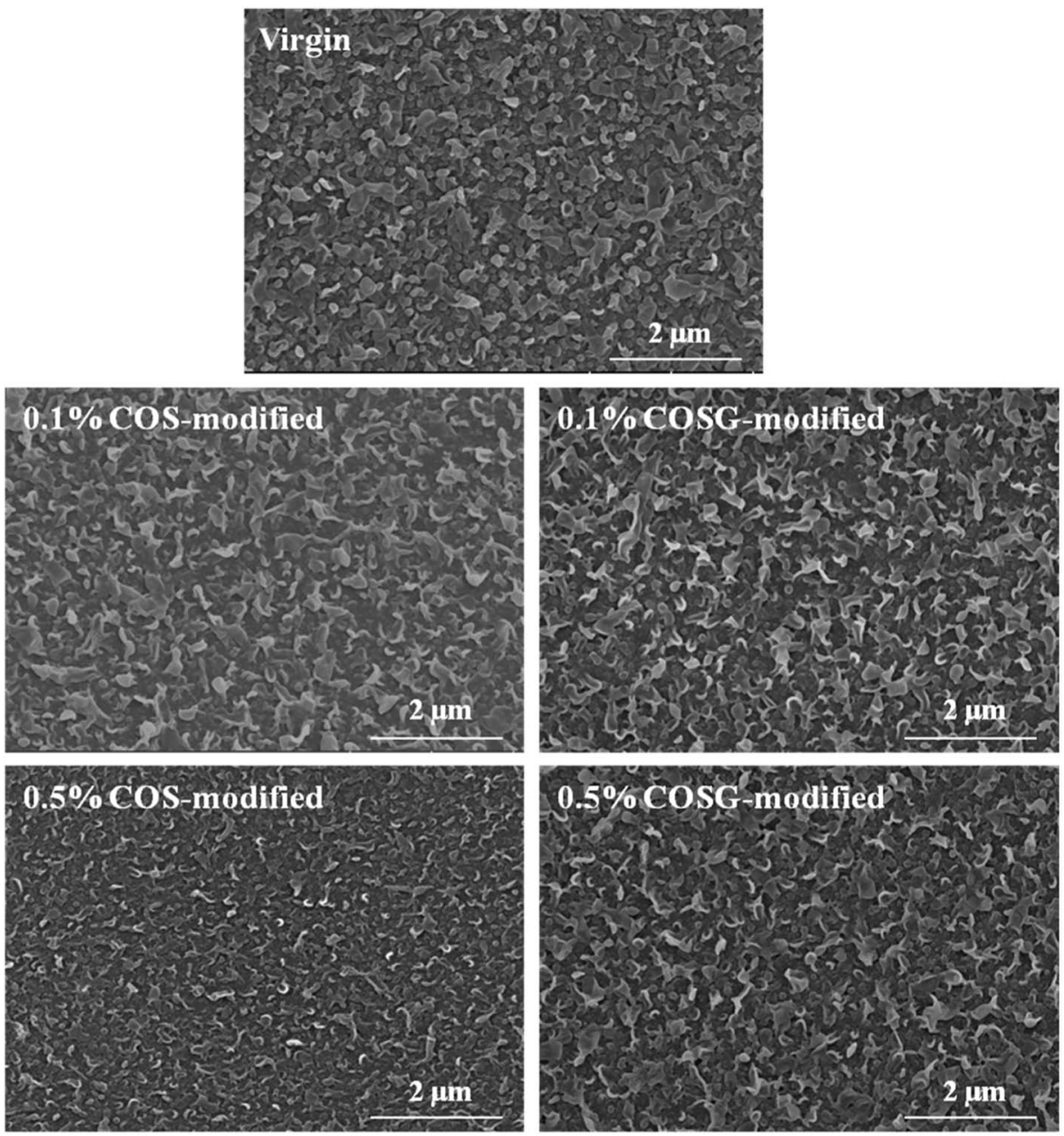

Fig. 6 SEM images of the virgin, COS-modified and COSG-modified membranes. 
modified membranes had higher oxygen $(\mathrm{O})$ atom content than the virgin membrane, owing to the higher relative $\mathrm{O}$ content $(-\mathrm{OH}, \mathrm{C}-\mathrm{O}-\mathrm{C})$ of $\mathrm{COS}$ in comparison with the aromatic polyamide layer. In addition, the membranes modified by COSG had higher content of nitrogen $(\mathrm{N})$ and lower content of carbon (C) compared with the COS-modified membranes due to the higher $\mathrm{N}$ element content of guanidyl. These results verified that COS and COSG had been successfully introduced to the membranes by second interfacial polymerization.

3.2.2. Surface charge analysis. The surface charge of the virgin and modified membrane was investigated through a streaming potential measurement at $\mathrm{pH} 7$ and $25{ }^{\circ} \mathrm{C}$. The results are presented in Table 1 . The virgin membrane was typical negatively charged attributing to the existence of the carboxylic acid groups. ${ }^{40}$ In comparison, the COS-modified and COSG-modified membranes had less negative charge. Typically, the zeta potential values of the membrane surfaces modified with $0.5 \%$ COS solution and $0.5 \%$ COSG solution were about $-10.62 \pm 2.82 \mathrm{mV}$ and $4.17 \pm 1.93 \mathrm{mV}$ at $\mathrm{pH} 7.0$, respectively. The almost neutral charged COSG-modified membrane was due to the protonation of primary amine groups on the COS and guanidine groups, which made the positive charge of the membranes increased. ${ }^{53}$ Meanwhile, the second IP process consumed the carboxylic acid groups on the selective layer. ${ }^{\mathbf{4 0 , 6 0}}$
These changes further proved the successful guanidination of COS and the successful grafting of COS and COSG on the RO membrane surface.

3.2.3. Surface morphology analysis. The surface morphology of the membrane was observed by SEM and AFM. As Fig. 6, the typical ridge-and-valley structures were clearly observed and no significantly visual difference was detected. The membrane surface roughness is shown in Fig. 7 and Table 2 . The roughness values of COS-modified and COSG-modified membrane surface declined with the increase of the modified

Table 2 Roughness of the virgin, COS-modified and COSG-modified membranes

\begin{tabular}{lccc}
\hline Sample & $R_{\mathrm{rms}}{ }^{a}(\mathrm{~nm})$ & $R_{\mathrm{a}}{ }^{b}(\mathrm{~nm})$ & $R_{\mathrm{p}-\mathrm{v}}{ }^{c}(\mathrm{~nm})$ \\
\hline Virgin & $53.0 \pm 1.1$ & $42.2 \pm 1.4$ & $437.4 \pm 16.1$ \\
$0.1 \%$ COS-modified & $51.9 \pm 1.6$ & $41.5 \pm 1.2$ & $413.5 \pm 13.8$ \\
$0.5 \%$ COS-modified & $48.6 \pm 1.3$ & $39.0 \pm 1.1$ & $379.3 \pm 12.6$ \\
$0.1 \%$ COSG-modified & $51.9 \pm 0.7$ & $41.8 \pm 0.9$ & $409.5 \pm 10.4$ \\
$0.5 \%$ COSG-modified & $44.5 \pm 1.2$ & $35.8 \pm 0.7$ & $366.6 \pm 11.3$
\end{tabular}

${ }^{a}$ Root mean square roughness. ${ }^{b}$ Average roughness. ${ }^{c}$ Peak-to-valley distance.

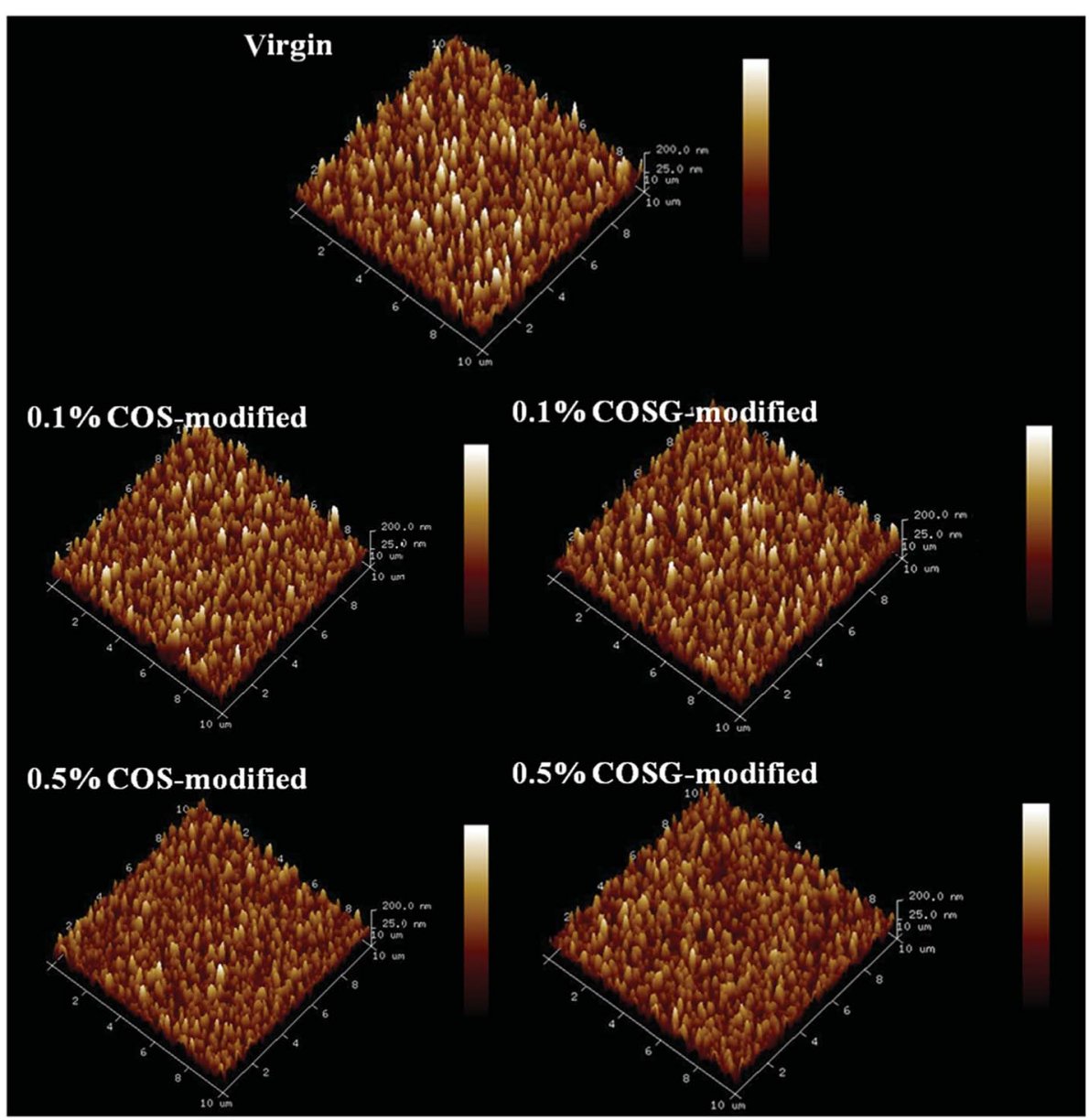

Fig. 7 AFM images of the virgin, COS-modified and COSG-modified membranes. 


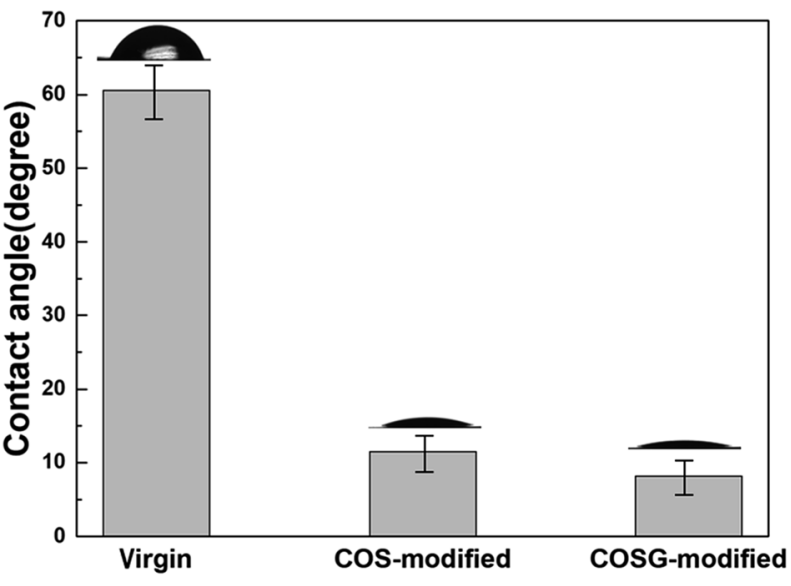

Fig. 8 Contact angles of the virgin, COS-modified and COSGmodified membranes.

solution concentration. For example, the $R_{\mathrm{p}-\mathrm{v}}$ declined from $437.4 \pm 16.1 \mathrm{~nm}$ of the virgin membrane to $366.6 \pm 11.3 \mathrm{~nm}$ of $0.5 \%$ COSG-modified membrane. This was because the COS and COSG polymer chains filled the valley structure of RO membrane surfaces.

SEM and AFM analysis results indicated that the influence of second interfacial polymerization on the surface morphology of membranes was negligible.

3.2.4. Wettability analysis. The membranes grafted with $0.5 \%$ COS and COSG solution were chosen to test the contact angle. As Fig. 8, the contact angle of the virgin membrane was $60.3 \pm 4.8^{\circ}$. The contact angles of COS-modified and COSGmodified membrane were $11.2 \pm 3.2^{\circ}$ and $8.1 \pm 3.6^{\circ}$, decreasing by $81.4 \%$ and $86.6 \%$ compared with the virgin membrane, respectively. It was due to the existence of polar groups (-OH, $-\mathrm{NH}_{2}, \mathrm{C}-\mathrm{O}-\mathrm{C}$ and guanidyl) in COS and COSG. ${ }^{61}$ The contact angle results might indicate the great increase of surface hydrophilicity after COS and COSG modification.

\subsection{Desalination performance analysis}

The desalination performance of the virgin, COS-modified and COSG-modified membranes were evaluated. As shown in Table 3 , the water fluxes of COS-modified and COSG-modified membranes increased obviously. Especially, the water fluxes of $0.5 \%$ COS-modified and $0.5 \%$ COSG-modified membranes were $58.12 \pm 2.10 \mathrm{~L} \mathrm{~m}^{-2} \mathrm{~h}^{-1}$ and $59.82 \pm 1.63 \mathrm{~L} \mathrm{~m}^{-2} \mathrm{~h}^{-1}$,

Table 3 Desalination performance of the virgin, COS-modified and COSG-modified membranes (test condition: $2000 \mathrm{mg} \mathrm{L}^{-1} \mathrm{NaCl}$, 1.55 MPa TMP, $1.5 \mathrm{~L} \mathrm{~min}^{-1}, 25.0 \pm 0.1{ }^{\circ} \mathrm{C}$ )

\begin{tabular}{lll}
\hline Sample & Water flux $\left(\mathrm{L} \mathrm{m}^{-2} \mathrm{~h}^{-1}\right)$ & Salt rejection $(\%)$ \\
\hline Virgin & $51.30 \pm 1.52$ & $99.03 \pm 0.21$ \\
$0.1 \%$ COS-modified & $54.57 \pm 1.63$ & $99.02 \pm 0.18$ \\
$0.5 \%$ COS-modified & $58.12 \pm 2.10$ & $98.75 \pm 0.09$ \\
$0.1 \%$ COSG-modified & $56.28 \pm 0.94$ & $98.92 \pm 0.13$ \\
$0.5 \%$ COSG-modified & $59.82 \pm 1.63$ & $98.91 \pm 0.12$
\end{tabular}

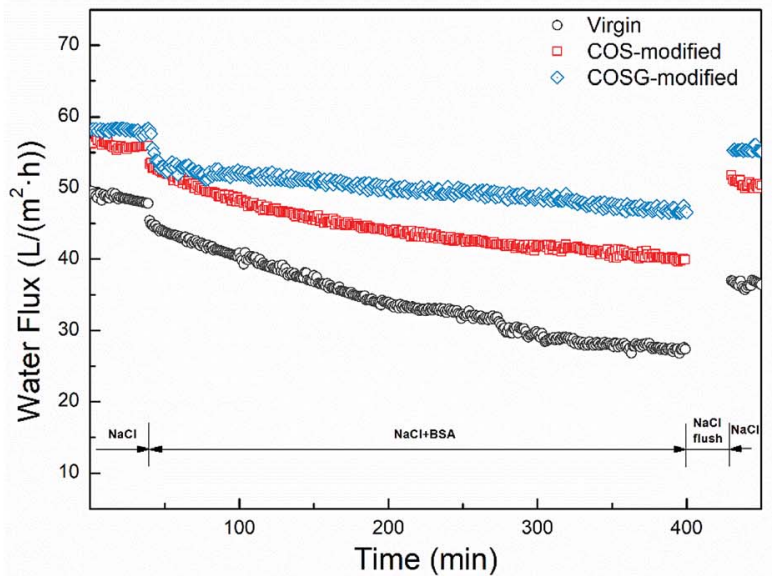

(a)

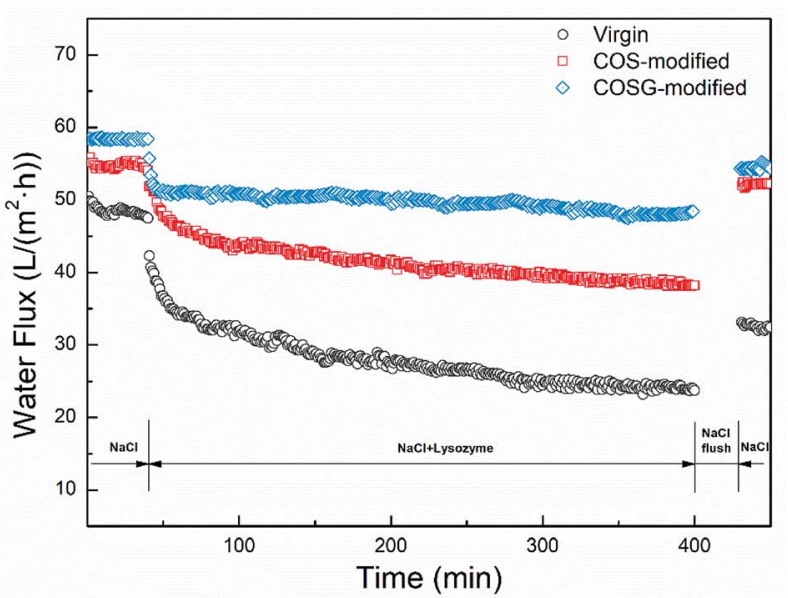

(b)

Fig. 9 The effect of BSA (a) and lysozyme (b) fouling on the water fluxes of the RO membranes (fouling condition: $2000 \mathrm{mg} \mathrm{L}^{-1} \mathrm{NaCl}$, $500 \mathrm{mg} \mathrm{L}^{-1}$ foulant, $1.55 \mathrm{MPa}$ TMP, $1.5 \mathrm{~L} \mathrm{~min}^{-1}, 25.0 \pm 0.1^{\circ} \mathrm{C}$; rinsing condition: $2000 \mathrm{mg} \mathrm{L}^{-1} \mathrm{NaCl}, 0.62 \mathrm{MPa}$ TMP, $4.0 \mathrm{~L} \mathrm{~min}^{-1}, 25.0 \pm 0.1$ $\left.{ }^{\circ} \mathrm{C}\right)$.

increasing by $13.29 \%$ and $16.61 \%$ compared with the virgin membrane, respectively. It was because the surface modified layer contained the hydrophilic amino, acylamide, hydroxy and guanidine. The enhanced surface hydrophilicity promoted the dissolution of water molecules in the membrane, which could increase the flux. ${ }^{62}$ Although the salt rejections of the modified membranes showed small decrease, the reductions were not significant. The small decrease may be due to the mild surface modification condition.

\subsection{Anti-fouling property}

In this work, the membranes grafted with $0.5 \%$ COS and COSG solution were chosen to conduct the fouling, anti-bacterial and biofouling experiments, because the membranes with this grafting concentration had a more hydrophilic, smoother, lower negatively charged surface, and better membrane permselectivities than the modified membranes with the other concentration. BSA and lysozyme were chosen to test the anti- 
Table 4 The flux decline and flux recovery of the virgin, COS-modified and COSG-modified membranes (fouling condition: $2000 \mathrm{mg} \mathrm{L}^{-1}$ $\mathrm{NaCl}, 500 \mathrm{mg} \mathrm{L}^{-1}$ foulant, $1.55 \mathrm{MPa} \mathrm{TMP}, 1.5 \mathrm{~L} \mathrm{~min}^{-1}, 25.0 \pm 0.1{ }^{\circ} \mathrm{C}$; rinsing condition: $2000 \mathrm{mg} \mathrm{L}^{-1} \mathrm{NaCl}, 0.62 \mathrm{MPa}$ TMP, $4.0 \mathrm{~L} \mathrm{~min}^{-1}, 25.0$ $\left.\pm 0.1^{\circ} \mathrm{C}\right)$

\begin{tabular}{lllll}
\hline Sample & & Virgin & COS-modified & COSG-modified \\
\hline \multirow{2}{*}{ BSA } & FD & $44.8 \%$ & $28.7 \%$ & $20.4 \%$ \\
& FR & $73.8 \%$ & $91.1 \%$ & $93.2 \%$ \\
Lysozyme & FD & $47.0 \%$ & $29.8 \%$ & $16.2 \%$ \\
& FR & $65.4 \%$ & $93.1 \%$ & $93.6 \%$
\end{tabular}

fouling performance of the membranes and the experiment were tested for $450 \mathrm{~min}$ at equal trans-membrane pressure. As Fig. 9, the water fluxes declined rapidly at first and slowed down gradually. The FD and FR are presented in Table 4. After fouling, the water flux declines of the COS-modified and COSG-modified membrane were low. Meanwhile, the COS-modified and COSGmodified membranes could recover over $91 \%$ water flux after rinsing, which were much higher than the virgin membrane. The improved surface hydrophilicity, smoother surface morphology and lower negative charge of the modified membranes weakened the interaction between the foulants and the modified membrane, resulting in less adsorption and easier removal of foulants from the membrane surface.

The surface morphology of membranes was characterized after fouling and rinsing. As shown in Fig. 10, the modified membranes had relatively less residual foulants and the ridgeand-valley structures were distinct.
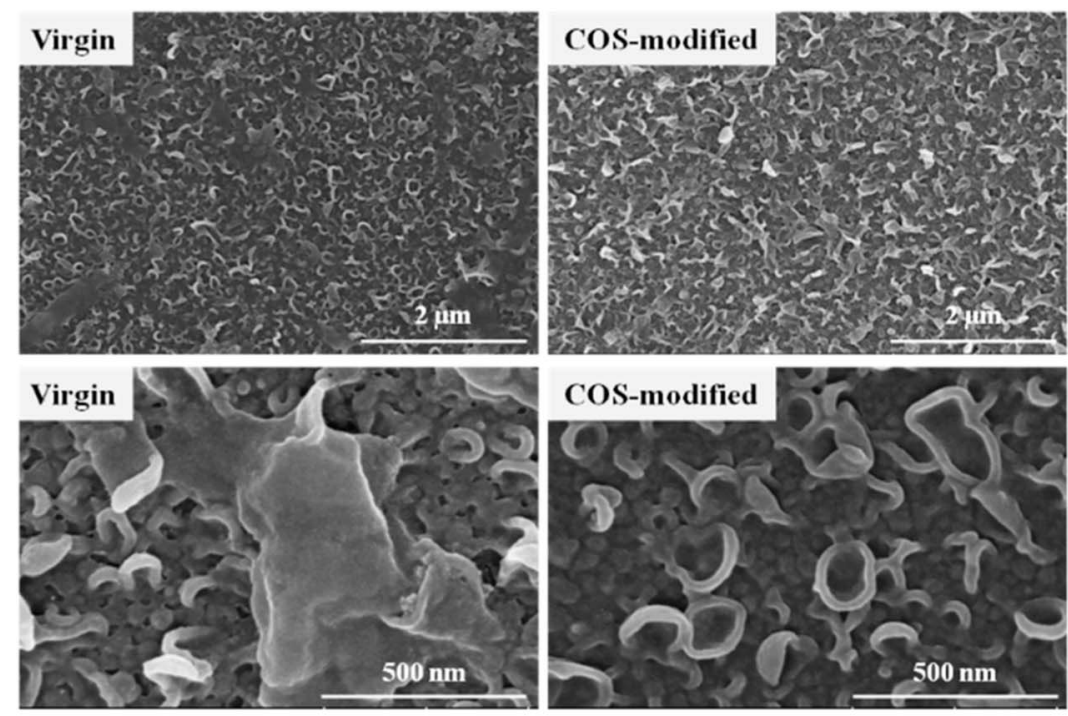

(a)
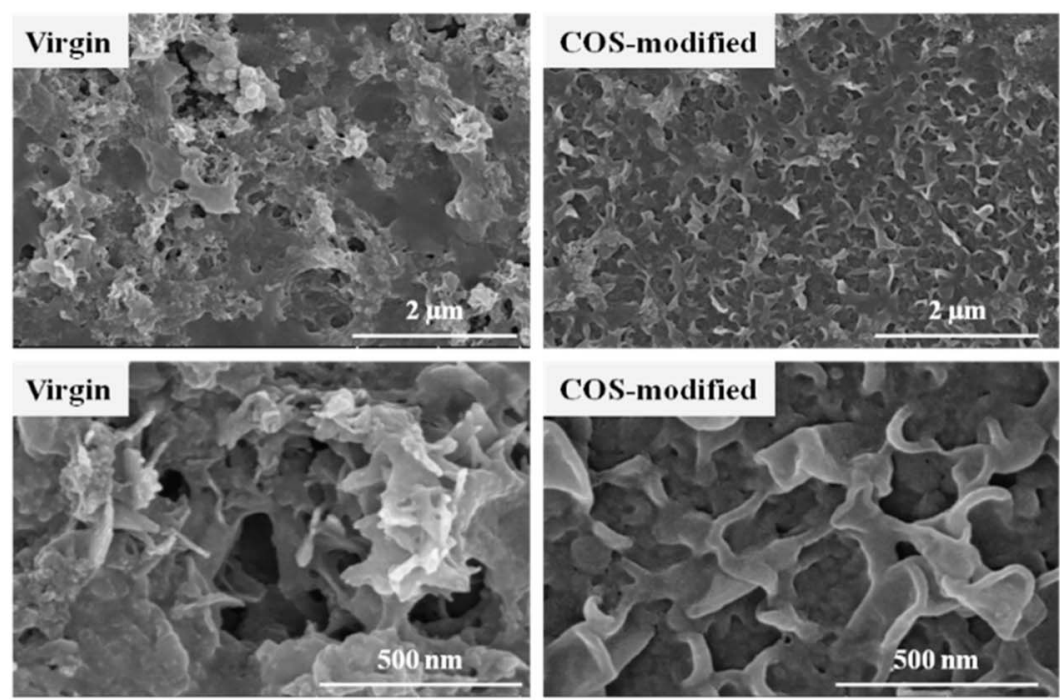

(b)
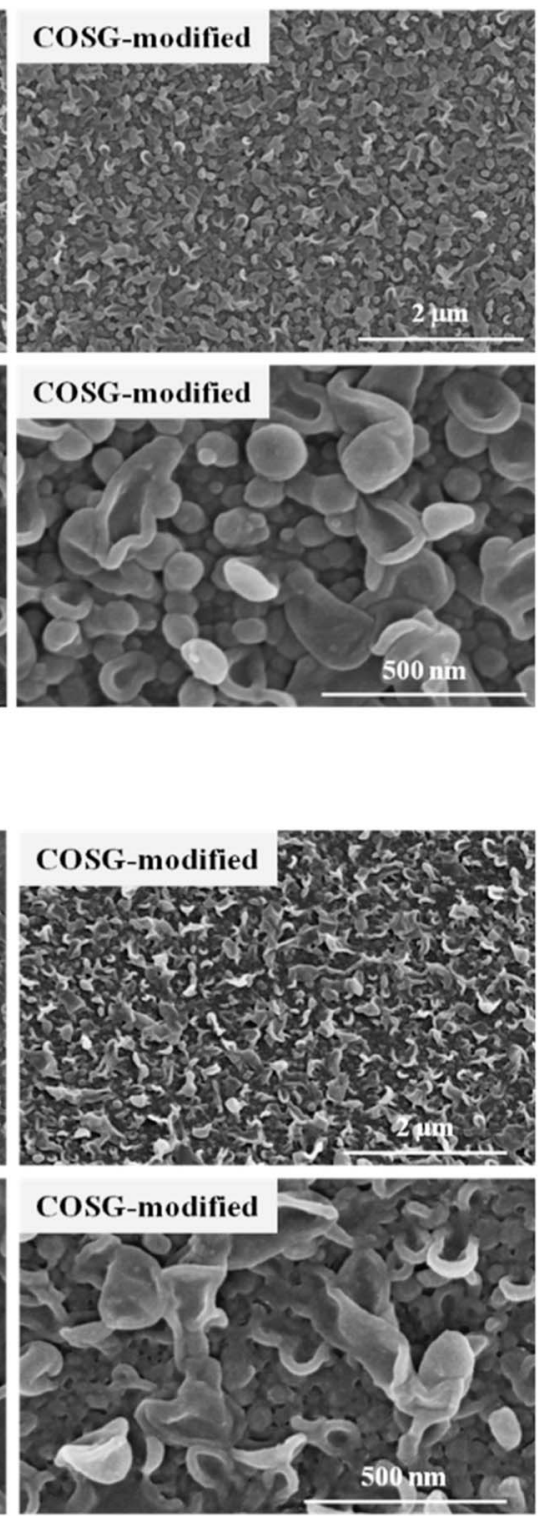

Fig. 10 SEM images of the RO membranes after BSA (a) and lysozyme (b) fouling (fouling condition: $2000 \mathrm{mg} \mathrm{L}^{-1} \mathrm{NaCl}^{2} 500 \mathrm{mg} \mathrm{L}-1$ foulant, 1.55 MPa TMP, $1.5 \mathrm{~L} \mathrm{~min}^{-1}, 25.0 \pm 0.1^{\circ} \mathrm{C}$; rinsing condition: $2000 \mathrm{mg} \mathrm{L}^{-1} \mathrm{NaCl}, 0.62 \mathrm{MPa} \mathrm{TMP}, 4.0 \mathrm{~L} \mathrm{~min}^{-1}, 25.0 \pm 0.1^{\circ} \mathrm{C}$ ). 

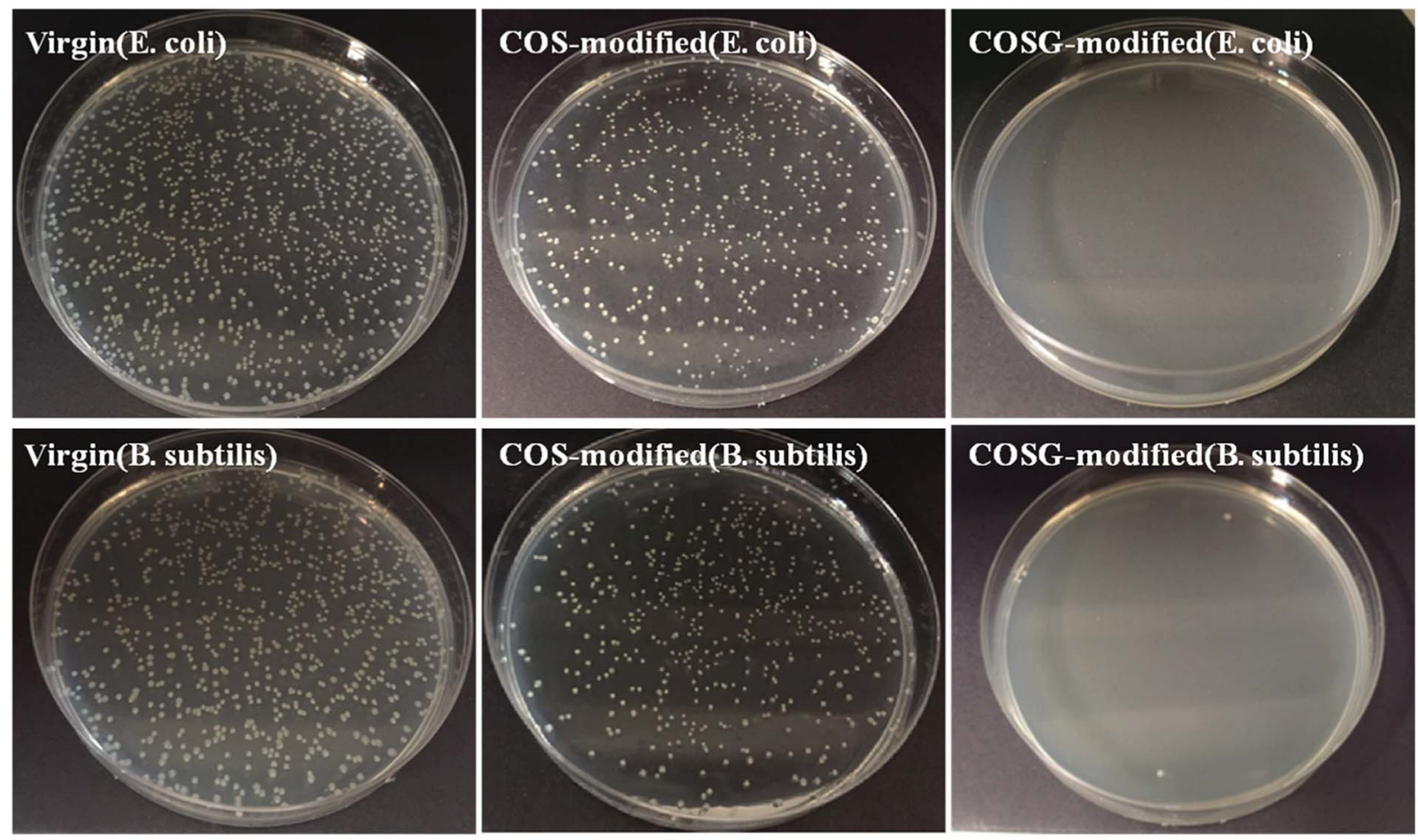

Fig. 11 The colonies of $E$. coli and B. subtilis suspensions after contacting with the RO membranes for $2 \mathrm{~h}$ (incubation level: $(5.3-8.0) \times 10^{7} \mathrm{CFU}$ $\mathrm{m}^{-2}$ ).

The above results indicated that the modified membranes were endowed with excellent anti-fouling property.

\subsection{Anti-bacterial property}

The sterilization property of the membranes were tested. As Fig. 11 and Table 5, the bacteria mortalities of the virgin membrane were about $25.0 \pm 4.0 \%$ and $28.0 \pm 2.2 \%$ for $E$. coli and $B$. subtilis, respectively. The bacteria mortalities of the COSmodified membrane were about $38.7 \pm 2.9 \%$ and $41.5 \pm 3.2 \%$

Table 5 The mortalities of $E$. coli and B. subtilis after contacting with the RO membranes (incubation level: $(5.3-8.0) \times 10^{7} \mathrm{CFU} \mathrm{m} \mathrm{m}^{-2}$; contact time: $2 \mathrm{~h}$ )

\begin{tabular}{lll}
\hline Sample & E. coli & B. subtilis \\
\hline Virgin & $25.0 \pm 4.0 \%$ & $28.0 \pm 2.2 \%$ \\
COS-modified & $38.7 \pm 2.9 \%$ & $41.5 \pm 3.2 \%$ \\
COSG-modified & $99.9 \%$ & $99.9 \%$
\end{tabular}

for E. coli and B. subtilis, respectively. The increased bacteria mortalities of COS-modified membranes were due to the protonated amine groups. It was supposed that the protonated amine groups might have the anti-bacterial property, because it could bind with the negatively charged macromolecules in bacteria cell leading to bacteria death. ${ }^{63,64}$

As presented in Fig. 11, almost no colony could be observed for the COSG-modified membrane. The bacteria mortalities of the COSG-modified membrane were $99.9 \%$ for the two kinds of bacteria, demonstrating the strong anti-bacterial property of COSG-modified membranes against both the Gram-positive bacteria and Gram-negative bacteria. The excellent antibacterial property of the COSG-modified membrane was attributed to the high-activity guanidine groups on the membrane surface. The strong electrostatic interaction of COSG and the bacteria changed the permeability of the cell membrane, and resulted in intracellular material leakage..$^{53}$ Finally, the bacteria lost biological activity.

Table 6 Flux and rejection of the membranes before and after biofouling test (inoculum level: $(5.3-8.0) \times 10^{7} \mathrm{CFU} \mathrm{m}^{-2}$ for E. coli and B. subtilis, $37^{\circ} \mathrm{C}, 7 \mathrm{~d}$; test condition: $2000 \mathrm{mg} \mathrm{L}^{-1} \mathrm{NaCl}, 1.55 \mathrm{MPa} \mathrm{TMP}, 1.5 \mathrm{~L} \mathrm{~min}{ }^{-1}, 25.0 \pm 0.1^{\circ} \mathrm{C}$ )

\begin{tabular}{|c|c|c|c|c|c|c|}
\hline Sample & \multicolumn{2}{|l|}{ Before biofouling } & \multicolumn{2}{|l|}{ E. coli } & \multicolumn{2}{|l|}{ B. subtilis } \\
\hline COS-modified & $58.12 \pm 2.10$ & $98.75 \pm 0.09$ & $53.3 \pm 1.8$ & $99.14 \pm 0.06$ & $56.8 \pm 1.3$ & $99.02 \pm 0.07$ \\
\hline COSG-modified & $59.82 \pm 1.63$ & $98.91 \pm 0.12$ & $54.8 \pm 1.1$ & $99.08 \pm 0.11$ & $56.7 \pm 0.9$ & $99.05 \pm 0.06$ \\
\hline
\end{tabular}



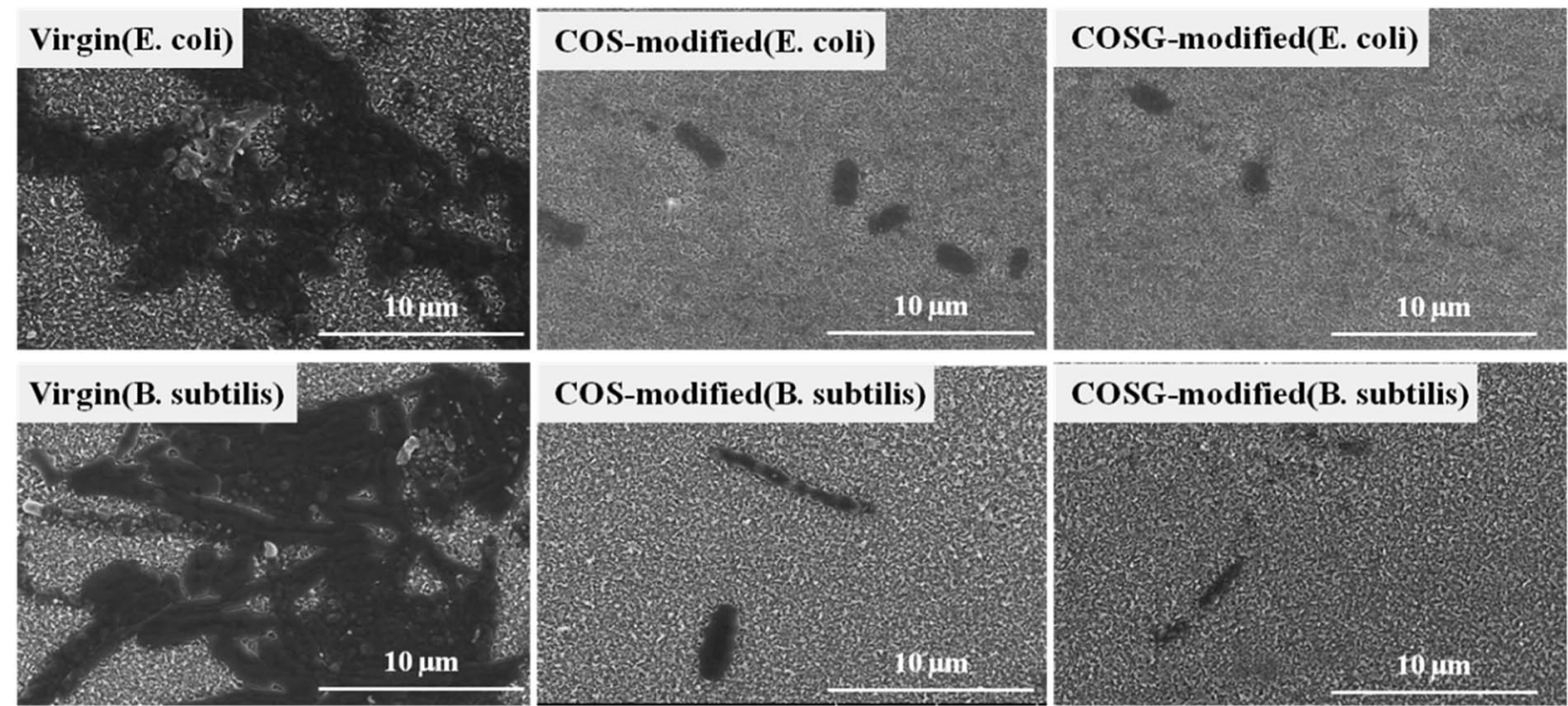

Fig. 12 SEM images of the RO membranes after contacting with $E$. coli and $B$. subtilis suspensions for 7 days and rinsing with pure water (incubation level: $(5.3-8.0) \times 10^{7} \mathrm{CFU} \mathrm{m}^{-2}$ ).

\subsection{Anti-biofouling property}

The desalination performance of the membranes after biofouling are shown in Table 6 . The water fluxes of the virgin membrane decreased about $29.4 \%$ and $20.2 \%$ of the initial flux for $E$. coli and B. subtilis, respectively. While the water fluxes of the COS-modified membrane decreased by $8.2 \%$ and $2.2 \%$, respectively. In addition, the COSG-modified membrane reduced about $8.4 \%$ and $5.2 \%$ of the initial water flux, respectively. Meanwhile, the modified membranes exhibited higher salt rejection than the virgin membrane. As Fig. 12, the membrane surface of COS-modified and COSG-modified membrane could be observed less adhered bacteria than the virgin membrane. These results demonstrated the excellent anti-biofouling characteristics of the modified membranes.

The bacterial colonies and the EPS, which were generated with the bacteria growing and reproduction could hinder the back diffusion of $\mathrm{NaCl}$. Eventually, the osmotic pressure increased and the desalination performance of the virgin membrane decreased. The hydrated layer of the hydrophilic surface (COS-modified and COSG-modified) improved the antibiofouling characteristics of the RO membrane by barricading against the adsorption of bacteria to the membrane surface. Meanwhile, the membrane modified with COSG exhibited a contact killing anti-bacterial property, which could prevent biofilm formation. Therefore, the modified membranes maintained high permselectivity.

\section{Conclusions}

In this work, a new anti-bacterial biguanidine functional chitooligosaccharide (COSG) was successfully synthesized and immobilized on the nascent RO membrane surface via second interfacial polymerization. The COSG fully combined the superiority of oligosaccharides and guanidine-based polymers, which possesses excellent hydrophilic and anti-bacterial properties. In addition, the modification method is simple, timeefficient and could be used for scale-up. The COSG-modified membrane showed neutral charge, significantly improved hydrophilicity and $16.61 \%$ increase of water flux. The membrane anti-fouling property was also improved with low flux decline ratios and high flux recovery ratios in organic fouling test. Moreover, the COSG-modified membrane exhibited killing ratio of $99.9 \%$ against $E$. coli and B. subtilis due to the high-activity guanidine groups. A small number of attached bacteria and the maintained permselectivity during severe biofouling tests confirmed the excellent anti-biofouling property of the COSG-modified membrane.

\section{Conflicts of interest}

There are no conflicts to declare.

\section{Acknowledgements}

This research was supported by Natural Science Foundation of China (No. 91534124), and Public Science and Technology Research Funds Projects of Ocean (No. 201405009).

\section{References}

1 L. F. Greenlee, D. F. Lawler, B. D. Freeman, B. Marrot and P. Moulin, Water Res., 2009, 43, 2317-2348.

2 M. Elimelech and W. A. Phillip, Science, 2011, 333, 712-717. 3 A. G. Fane, R. Wang and M. X. Hu, Angew. Chem., Int. Ed., 2015, 54, 3368-3386.

4 D. M. Warsinger, S. Chakraborty, E. W. Tow, M. H. Plumlee, C. Bellona, S. Loutatidou, L. Karimi, A. M. Mikelonis, A. Achilli, A. Ghassemi, L. P. Padhye, S. A. Snyder, 
S. Curcio, C. D. Vecitis, H. A. Arafat and J. H. Lienhard, Prog. Polym. Sci., 2018, 81, 209-237.

5 M. Asadollahi, D. Bastani and S. A. Musavi, Desalination, 2017, 420, 330-383.

6 Q. Li and M. Elimelech, Environ. Sci. Technol., 2004, 38, 46834693.

7 G. Kang and Y. Cao, Water Res., 2012, 46, 584-600.

8 R. A. Al-Juboori and T. Yusaf, Desalination, 2012, 302, 1-23.

9 A. Ettori, E. Gaudichet-Maurin, J.-C. Schrotter, P. Aimar and C. Causserand, J. Membr. Sci., 2011, 375, 220-230.

10 T.-S. Kim and H.-D. Park, J. Membr. Sci., 2016, 507, 24-33.

11 X. Huang, K. L. Marsh, B. T. McVerry, E. M. V. Hoek and R. B. Kaner, ACS Appl. Mater. Interfaces, 2016, 8, 1433414338.

12 S.-H. Park, S. H. Kim, S.-J. Park, S. Ryoo, K. Woo, J. S. Lee, T.-S. Kim, H.-D. Park, H. Park, Y.-I. Park, J. Cho and J.-H. Lee, J. Membr. Sci., 2016, 513, 226-235.

13 Y. Wang, Z. Wang, X. Han, J. Wang and S. Wang, J. Membr. Sci., 2017, 539, 403-411.

14 S.-H. Park, S. O. Hwang, T.-S. Kim, A. Cho, S. J. Kwon, K. T. Kim, H.-D. Park and J.-H. Lee, Appl. Surf. Sci., 2018, 443, 458-466.

15 M. Piatkovsky, H. Acar, A. B. Marciel, M. Tirrell and M. Herzberg, J. Membr. Sci., 2018, 549, 507-514.

16 Z. Yang, D. Saeki and H. Matsuyama, J. Membr. Sci., 2018, 550, 332-339.

17 D. Rana and T. Matsuura, Chem. Rev., 2010, 110, 2448-2471.

$18 \mathrm{~K}$. Boussu, C. Vandecasteele and B. Van der Bruggen, J. Membr. Sci., 2008, 310, 51-65.

19 A. R. D. Verliefde, E. R. Cornelissen, S. G. J. Heijman, J. Q. J. C. Verberk, G. L. Amy, B. Van der Bruggen and J. C. van Dijk, J. Membr. Sci., 2008, 322, 52-66.

20 Y. Zhou, S. Yu, C. Gao and X. Feng, Sep. Purif. Technol., 2009, 66, 287-294.

21 L. Zhao, P. C.-Y. Chang, C. Yen and W. S. Winston Ho, J. Membr. Sci., 2013, 425, 1-10.

22 M. Liu, Q. Chen, L. Wang, S. Yu and C. Gao, Desalination, 2015, 367, 11-20.

$23 \mathrm{~J} . \mathrm{Wu}, \mathrm{Z}$. Wang, Y. Wang, W. Yan, J. Wang and S. Wang, J. Membr. Sci., 2015, 495, 1-13.

24 Y. Wang, Z. Wang and J. Wang, J. Membr. Sci., 2018, 554, 221-231.

25 F. Perreault, M. E. Tousley and M. Elimelech, Environ. Sci. Technol. Lett., 2014, 1, 71-76.

26 H. Isawi, M. H. El-Sayed, X. Feng, H. Shawky and M. S. Abdel Mottaleb, Appl. Surf. Sci., 2016, 385, 268-281.

27 C. Dong, Z. Wang, J. Wu, Y. Wang, J. Wang and S. Wang, Desalination, 2017, 401, 32-41.

28 Q. Yu, J. Cho, P. Shivapooja, L. K. Ista and G. P. Lopez, ACS Appl. Mater. Interfaces, 2013, 5, 9295-9304.

29 C. X. Liu, D. R. Zhang, Y. He, X. S. Zhao and R. Bai, J. Membr. Sci., 2010, 346, 121-130.

30 G. Ye, J. Lee, F. Perreault and M. Elimelech, ACS Appl. Mater. Interfaces, 2015, 7, 23069-23079.

31 P. Gilbert and L. E. Moore, J. Appl. Microbiol., 2005, 99, 703715.
32 F. C. Krebs, S. R. Miller, M. Lee Ferguson, M. Labib, R. F. Rando and B. Wigdahl, Biomed. Pharmacother., 2005, 59, 438-445.

33 Y. Guan, H. Xiao, H. Sullivan and A. Zheng, Carbohydr. Polym., 2007, 69, 688-696.

34 Y. K. Mathurin, R. Koffi-Nevry, S. T. Guehi, K. Tano and M. K. Oule, J. Food Prot., 2012, 75, 1167-1171.

35 V. Perla and S. S. Jayanty, Food Chem., 2013, 138, 1574-1580.

36 A. M. Salgueiro, M. D. Santos, J. A. Saraiva, F. Almeida, I. Sousa, J. Tedim, H. I. S. Nogueira and D. V. Evtuguin, Carbohydr. Polym., 2017, 175, 303-310.

37 D. Wei, Q. Ma, Y. Guan, F. Hu, A. Zheng, X. Zhang, Z. Teng and H. Jiang, Mater. Sci. Eng., C, 2009, 29, 1776-1780.

38 J. Nikkola, X. Liu, Y. Li, M. Raulio, H.-L. Alakomi, J. Wei and C. Y. Tang, J. Membr. Sci., 2013, 444, 192-200.

39 X. Li, Y. Cao, H. Yu, G. Kang, X. Jie, Z. Liu and Q. Yuan, J. Membr. Sci., 2014, 466, 82-91.

40 Y. Gao, S. Zhao, Z. Qiao, Y. Zhou, B. Song, Z. Wang and J. Wang, Desalination, 2018, 430, 74-85.

41 H. Zhang, Y. Gao and J. Gai, J. Mater. Chem. A, 2018, 6, 64426454.

42 M. Kong, X. G. Chen, K. Xing and H. J. Park, Int. J. Food Microbiol., 2010, 144, 51-63.

43 J. Dou, Q. Xu, C. Tan, W. Wang, Y. Du, X. Bai and X. Ma, Carbohydr. Polym., 2009, 75, 119-124.

44 S.-K. Kim and N. Rajapakse, Carbohydr. Polym., 2005, 62, 357-368.

45 K. V. Harish Prashanth and R. N. Tharanathan, Trends Food Sci. Technol., 2007, 18, 117-131.

46 M. Shen, S. Keten and R. M. Lueptow, J. Membr. Sci., 2016, 506, 95-108.

47 M. Shen, S. Keten and R. M. Lueptow, J. Membr. Sci., 2016, 509, 36-47.

48 K. Li, L. Liu, H. Wu, S. Li, C. Yu, Y. Zhou, W. Huang and D. Yan, Phys. Chem. Chem. Phys., 2018, 20, 29996-30005.

49 T. Wei, L. Zhang, H. Zhao, H. Ma, M. S. J. Sajib, H. Jiang and S. Murad, J. Phys. Chem. B, 2016, 120, 10311-10318.

50 N. Zhang, S. Chen, B. Yang, J. Huo, X. Zhang, J. Bao, X. Ruan and G. He, J. Phys. Chem. B, 2018, 122, 4719-4728.

51 X. Zhao, Z.-Z. Qiao, J.-X. He and S. Yiang, J. Eng. Fibers Fabr., 2010, 5, 16-24.

52 L. Wang, Z. Liu, X. Liu and Y. Wu, RSC Adv., 2016, 6, 9077790785.

53 P. Sahariah, B. M. Óskarsson, M. Á. Hjálmarsdóttir and M. Másson, Carbohydr. Polym., 2015, 127, 407-417.

54 M. Shi, Z. Wang, S. Zhao, J. Wang, P. Zhang and X. Cao, J. Membr. Sci., 2018, 555, 157-168.

55 W. Yan, Z. Wang, J. Wu, S. Zhao, J. Wang and S. Wang, J. Membr. Sci., 2016, 498, 227-241.

56 P. Fievet, M. Sbaï, A. Szymczyk, C. Magnenet, C. Labbez and A. Vidonne, Sep. Sci. Technol., 2004, 39, 2931-2949.

57 S. Tardu, Superlattices Microstruct., 2004, 35, 513-529.

58 Y. Gao, L. Liang, S. Zhao, Y. Qi, W. Zhang, X. Sun, Z. Wang, J. Wang and B. Song, RSC Adv., 2018, 8, 24690-24700.

59 Q. Liu, Y. Li, X. Jin, Q. Peng, X. Liu and Y. Wu, J. Appl. Polym. Sci., 2016, 25, 133. 
60 Y. Wang, Z. Wang, J. Wang and S. Wang, J. Membr. Sci., 2018, 549, 495-506.

61 A. Shakeri, H. Salehi and M. Rastgar, Carbohydr. Polym., 2017, 174, 658-668.

62 J. Xu, X. Feng and C. Gao, J. Membr. Sci., 2011, 370, 116-123.
63 J. Y. Kim, J. K. Lee, T. S. Lee and W. H. Park, Int. J. Biol. Macromol., 2003, 32, 23-27.

64 Y.-X. Mei, X.-Y. Dai, W. Yang, X.-W. Xu and Y.-X. Liang, Int. J. Biol. Macromol., 2015, 77, 330-335. 